\title{
China's 14th Five-year Plan: New Possibility in the Pandemic Period International Cooperation
}

\author{
Ruiwen Liu ${ }^{1, *}$ \\ ${ }^{1}$ Australian National University, Canberra, Australia \\ *Corresponding author. Email: guanghua.ren@gecacademy.cn
}

\begin{abstract}
As COVID-19 brings a huge crisis for countries all over the world, the economic downturn caused by the pandemic is not just a result of worldwide travel restrictions but also the incapability of national efforts. The crisis has made countries around the world once again realize the importance of globalization and cooperation between countries. However, China's 14th Five-year Plan, which was released in 2021, proposes a "Domestic-international Dual Circulation" economic development model, saying that China will shift its economic development focus from the international market to the domestic market in the next five years. The Chinese government has chosen to encourage the development of the domestic e-commerce economy to stimulate the vitality of the domestic market. By contrast, European countries, although isolated in the early stages of the outbreak, chose to help each other out as the global epidemic gradually worsened. China's unusual choice to focus on the domestic market is not a sign of anti-globalization or abandonment of the international market. It chooses to encourage the development of the e-commerce economy to explore the new structure and new development model of economic globalization in the future.
\end{abstract}

Keywords: COVID-19, China's $14^{\text {th }}$ Five-Year Plan, globalization, inter-state cooperation

\section{INTRODUCTION}

In 2020, coronavirus disease, as a highly infectious disease, started in China and spread rapidly around the world. So far, almost 5 million people have died from COVID-19 globally, making it one of the deadliest pandemics in human history [1]. The economic downturn caused by the pandemic is a huge crisis for the world. An increase in the number of cases and restrictive policies adopted by governments to curb the spread of the disease has led to a sharp drop in market demand and a worldwide shortage of workers. The International Monetary Fund (IMF) says the economic downturn caused by the coronavirus is far worse than the 2008 global financial crisis [2]. To reduce the impact of COVID-19, countries have introduced policies that limit people's social behavior and reduce international exchanges. Based on the blockade, the world economy suffered a huge shock. International business is at a standstill due to shutdowns of companies, strikes on production lines and lack of staff. This situation has made countries around the world increasingly aware of the need for globalization and global interaction.
In its 14th Five-Year Plan, released in the spring of 2021, China stressed building a bigger domestic market and restructuring its future development pattern. In addition, it also puts forward the concept of digital China, which means the Chinese government will accelerate digital development in the next five years. Against the backdrop of COVID-19 and the global economic crisis, the Chinese government has put forward new policies that focus more on the domestic market and domestic technology development. According to the strategy, China needs to strengthen the leading role of domestic circulation, improve the efficiency and level of domestic circulation and international circulation. That means to realize the mutual promotion of domestic and international circulation. Compared with the reawakening of globalization in other countries, China has chosen a completely different development strategy. These new policies will make China more dependent on domestic production capacity and less on international cooperation. In the context of the global economic crisis caused by COVID-19, is China's choice to shift its economic focus to the domestic market an expression of anti-globalization?

This paper takes the development of China's ecommerce economy as an example to analyze the 
significance of encouraging e-commerce economic development strategies in the face of the global economic recession caused by COVID-19. It discusses the development of the e-commerce economy to realize the "Domestic-international Dual Circulation" of the new economic development strategy. By observing the attitude of China and Europe in dealing with the economic crisis, this paper discusses whether the "Domestic-international Dual Circulation" economic development strategy proposed by China in the 14th Five-Year Plan means that China implements the economic policy against economic globalization.

\section{THE DEVELOPMENT OF E- COMMERCE ECONOMY IN CHINA}

The growth of China's e-commerce economy is closely related to the two economic downturns caused by infectious diseases in the 21 st century. The year 2003 was the initial stage of development of China's e-commerce economy. By 2020, the e-commerce economy has been widely recognized in China. Faced with the global economic recession in 2020 and the contraction of the domestic market, the Chinese government chose to change its economic policies and vigorously encourage the development of the e-commerce economy, and decided to form a new development path of double circulation of the domestic and international market economy dominated by e-commerce economy in the future. The economic recession caused by the COVID-19 pandemic, which has had a huge impact on the whole world, is a new way of thinking for China's economic development. From the perspective of economic theory, the recession crisis of COVID-19 has made the Chinese government realize that the development of the ecommerce economy can no longer be allowed to carry out free-market competition based on classical economic theories. As an important driving force for the recovery of China's domestic economic vitality, the government's normative policies and encouraging development policies can better promote the e-commerce economy and contribute to China's future economic development.

\section{CLASSICAL ECONOMICS}

In the early stage of the development of the ecommerce economy, the Chinese government adopted the market mechanism of free competition in classical economics, which provided conditions for the free development of the digital economy. After analyzing the market mechanism of free competition, classical economics confirms the regulating effect of the market on economic activities. Classical economists believe that the market is the "invisible hand" that controls social and economic activities and can self-regulate economic activities through the gradual balance between market demand and supply. Therefore, classical economics opposes state intervention in the market economy and advocates the principle that the market should be left to its own devices. In the face of the development of the market, the state should abide by its rules of free competition and survival of the fittest and should not interfere.

In 2003, the outbreak of SARS made China's economy face a terrible situation of rapid recession in a short time. Alibaba, which was at a critical stage of rapid growth at the time, was in trouble because of infection among its employees. But Alibaba took advantage of the situation by launching Taobao and choosing to do foreign trade through the Internet. This change not only enabled Alibaba to discover new business opportunities and grow its business at a rate of more than $50 \%$ but also enabled Alibaba's e-commerce model to quickly become known in China and around the world [3]. Liu Qiangdong, the founder of jd.com, another retail e-commerce giant in China, has publicly admitted that during the SARS period when all the computer stores in Zhongguancun were shut down, he began to seriously consider e-commerce and eventually embarked on the road to full-scale online ecommerce.

In 2003, SARS caused a rapid economic recession in China in a short period, but also made the digital economy appear in consumers' eyes. During the SARS epidemic in 2003, many people started using the Internet and tried to conduct online transactions due to the policy of home isolation. This epidemic has provided an environment for the growth of the e-commerce economy, ideas for its development. In 2003, the Internet was not universal. At the same time, in the initial stage of the ecommerce economy, the logistics system is also very backward, so the e-commerce economy has not received enough attention. Faced with the initial development of the e-commerce economy, the Chinese government did not intervene and encouraged too much. At that time, China's e-commerce economic market was still in the initial stage of free competition. The Chinese government also created a good environment for its development [4]. At that time, The Chinese government insisted on the classical economic theory, hoping to form a virtuous cycle development model of the digital economy through the natural circulation of capital.

\section{KEYNESIAN}

The biggest difference between economists who support Keynesian economic theory and others is that they believe that aggressive economic policies can reduce the volatility of the business cycle. Instead of relying on the free market competition for free recovery, the government should take measures to solve economic problems quickly and in a short period. The market is capable of self-regulation, but it is also a long process of competition and recovery. In contrast to 2003, when China adopted a policy of respecting free-market competition, in 2020, the Chinese government believes 
that it should adopt aggressive economic policies to reduce the volatility of the business cycle. Moreover, the two economic recessions, both have the characteristics of a short recession cycle and great impact on the short-term economy. Under such circumstances, the Chinese government did not rely on the free competition of the market to recover the economy slowly but took measures to solve the economic problems in a short time. For a recession caused by the pandemic, the market needs a quick recovery, not a long wait.

Meanwhile, another difficulty facing China's economic recovery in 2020 is the disruption of global trade. With the continuous spread of the epidemic, the economy of almost all countries in the world has been affected to varying degrees. The shortage of labor and the fracture of the capital chain caused the economic market of the world to stagnant gradually, even producing the situation of recession. The country's imports and exports have also become more difficult due to the epidemic prevention and control. Faced with such a situation, the Chinese government chose to rely on the digital economy to quickly restore the vitality of the domestic market. The e-commerce economy ushered in a new stage of rapid development. In one year, the proportion of the ecommerce economy in China's GDP increased from $20 \%$ to $34.8 \%$ [5]. Moreover, due to the state's encouraging policies on the e-commerce economy, in the first quarter of 2020 alone, China's rural e-commerce exceeded 13 million. The online retail sales of agricultural products reached 93.68 billion yuan, an increase of $31 \%$ [6]. Since the beginning of 2020, live streaming has become an unprecedented boom, with an annual turnover of 100 billion levels, making live streaming become the mainstream of new business models in the future. Li Jiaqi and Viya, two of China's most popular influencers, set a record of 3.5 billion yuan worth of deals in March. On Singles' Day in 2020, live-streaming sales for one night totaled nearly 7 billion yuan in their channels. During the pandemic, China's e-commerce economy has shown a new trend of rapid development.

Compared with the traditional offline economy, the ecommerce economy has stronger flexibility, mainly reflected in the operation time and operation mode. During the epidemic, the Chinese government's home isolation policy not only prevented offline transactions in China's offline markets but also prevented people from shopping offline to meet their daily needs. Under such circumstances, if the state wants to restore the vitality of China's internal economic market, an e-commerce economy is the best choice. Although the e-commerce economy in China has experienced more than ten years of development, the intervention policies and encouraging policies adopted by the Chinese government during the epidemic period have brought new vitality to the e-commerce economy. The e-commerce economy will not only help China bounce back quickly in the face of a recession, but also play a huge role in driving demand and expanding the domestic market in the future.

Since China joined the WTO in 2001, it has become accustomed to developing under the favorable conditions of globalization. In the past decade, under the trend of globalization, China has achieved sustained and rapid economic growth by relying on the world market. However, since the outbreak of COVID-19 in 2020, China's external environment has changed more dramatically, which has also made the Chinese government rethink the direction of China's future development and the new challenges it faces. China must appropriately adjust its development strategy to cope with the economic downturn and achieve sustainable development in the future. According to $\mathrm{Wu}$, in the early 21 st century, due to China's weak economic foundation and limited domestic market, expanding external markets to drive economic growth has become a very successful model. However, in future development, to reduce the uncertainties of external factors and the international market, China must gradually increase the proportion of domestic demand and domestic market in China's economic growth, to form a new driving force for sustainable development [7]. The government's encouragement of an e-commerce economy is an attempt to shift the market's focus.

In China's 14th Five-year Plan, the Chinese government believes that in China's development plan for the next five years, it is necessary to establish an effective system to expand domestic demand, speed up the cultivation of a complete domestic demand system, and build a strong domestic market. The new economic development model emphasizes the need to strengthen the domestic market to play a leading role in the cycle. At the same time, it also needs to rely on the international development cycle to improve the efficiency and level of the domestic development cycle, to realize the role of domestic and international dual circulation to promote each other and jointly promote the development of China's economy. In recent years, with the slowdown of global economic growth, the slowdown of the process of globalization and the increase of uncertainties in the process of trade liberalization, China's digital economy, represented by e-commerce, has achieved tremendous development and played an important role in promoting the domestic economic development. E-commerce has made positive contributions to promoting consumption, stabilizing foreign trade, helping China to help poor areas, expanding the domestic job market and driving the digital transformation of industries. Despite the sudden impact of the epidemic on China's economic development, ecommerce has shown strong vitality and resilience. In contrast to China's previous development strategy, China will shift its economic focus from the international market to the domestic market in the next five years, and through the support and control of e-commerce 
development, to achieve the goal of expanding domestic demand in the domestic market.

\section{COVID-19 AND EUROPEAN INTEGRATION DEVELOPMENT}

In the context of the impact of COVID-19 on the global economy, the prospects of globalization have also been questioned. Concepts such as "de-globalization" and "slowbalization" also reflect people's concerns about the prospects of globalization. The rapid spread of the virus around the world has made it more difficult for countries to implement policies to slow the spread of the virus. Australia is one of the countries tightening border controls as COVID-19 spreads around the world. Since February 1, 2020, the country has banned entry to foreign nationals who have visited the Chinese mainland. Prime Minister Scott Morrison said on March 18 that the federal government had updated its travel advice for Australian citizens, asking all Australians "not to travel abroad". In addition to the travel ban, the EU had a slow and fragmented initial response to the sudden public health crisis of COVID-19 in early 2020. The fight against the epidemic is being led by national governments. The spread of the disease in Europe has not been well controlled due to its sudden onset and rapid spread.

On 21 February 2020, Italy announced the confirmation of its first indigenous case. According to the ECDC, between 22 February and 7 March 2020, the first novel Coronavirus cases were confirmed in 16 European countries, all of which were caused by export cases from Italy. Since then, the disease has spread from country to country in Europe. Italy was the first country in Europe to announce its cases, and the government called for solidarity among European Union countries to help Italy. However, member states failed to respond to Italy's call for additional supplies of medical equipment, including masks. With Italy in dire need of aid, European Union countries such as Germany and France have imposed restrictions on the export of protective medical equipment. Instead, China offered to sell Italy medical equipment related to epidemic prevention, including ventilators, masks and protective suits. Italy's ambassador to the EU complained at a leaders' summit about a lack of solidarity among EU member states, which are refusing to help amid the pandemic. "Today, this means Italy; Tomorrow, the need could be elsewhere. Italy has already asked to activate the European Union mechanism of civil protection for the supply of medical equipment for individual protection. But, unfortunately, not a single EU country responded to the Commission's call. Only China oxide bilaterally. Certainly, this is not a good sign of European solidarity."

The outbreak began in China, where the news and statistics kept warning the world that it would be a catastrophe. In a short period, a large number of patients poured into the hospital for medical treatment, resulting in an excessive number of hospital patients, which is a huge test for medical staff. Secondly, the Coronavirus has shown its characteristics of rapid transmission and high mortality rate at an early stage. Finally, the Chinese government took strict measures, such as sealing off the affected areas and canceling all New Year celebrations, to stop the spread of the disease. China's cautionary tale has not raised alarm in Europe. European governments were confident that the few initial outbreaks were entirely under their control. The government believes that the rapid spread and high death rate of the outbreak will cause panic among the public. So, the government did not choose to inform the public of social distancing to control the spread of the disease. In Zhao Chen's research, he believed that at the initial stage of the concentrated outbreak in Europe, the EU, which could only play the role of an international organization, had unsatisfactory performance in both guidance and coordination, especially the comparison between the reference points of the WHO and China, which made the EU even more embarrassed. The COVID-19 pandemic is an exogenous shock to Europe, a test of the resilience of European integration. Through this crisis, the EU can also promote integration and strengthen the common goals of its member states [8]. The crisis is forcing countries around the world to reassess the global economy and cooperation between countries, as supply chains on world markets break down and countries run short of medical supplies. The COVID-19 pandemic has exposed the fragility of the globalized system, as viruses and epidemics have followed globalization to destroy the world economy and plunge the world into crisis. However, the crisis has also re-awakened the world to the importance of cooperation between nations and the importance of globalization.

As the disease spreads across Europe, the EU is aware of the negative impact of a slow response on Europe's response to the disease. European countries have also realized the need for cooperation and embarked on a mutually beneficial fight against the virus [9]. The 17 euro-zone countries in the European Union have ceded monetary-policy decision-making to the European Central Bank. The European Central Bank has the power to set benchmark deposit rates for the 17 countries. In the wake of the outbreak, the European Central Bank, to boost confidence and liquidity in Europe, The ECB announced that it would purchase an additional 120 billion euros of sovereign or corporate bonds and an additional 750 billion euros of "pandemic emergency purchase program", including the bonds of Italy and Greece and other heavily indebted countries, to show that it is willing to cover the cost of the eurozone countries to fight the epidemic. German Chancellor Angela Merkel also used the concept of a "community of common destiny" for the first time in a government statement ahead of the video summit. "We are a community of shared destiny. Europe must prove that during the pandemic," she said. The President of the European 
Council Charles Michel highlighted four priorities for the EU to tackle, limiting the spread of the virus, ensuring the supply of medical equipment to member states, promoting vaccine development and treatment. The European Commission will also purchase protective equipment to provide to member states. The COVID-19 pandemic has exposed previous conflicts of interest among EU member states, as well as the fact that the integration of the European region has enabled EU member states to jointly cope with the negative impact of the pandemic.

\section{COVID-19 AND GLOBALIZATION OF CHINA}

As one of the earliest sources of the epidemic, China has actively assisted other countries around the world after initially controlling the epidemic. In the report "China's Actions against COVID-19" released on June 7, 2020, China expressed its sympathy for the increasingly severe global epidemic situation and was willing to provide support and assistance to all parties to the best of its ability and share its experience and solutions without reservation. As of May 31 in 2020, China has sent 29 medical teams to 27 countries and has provided or is providing anti-epidemic assistance to 150 countries and four international organizations. From March 1 to May 31, China exported 70.6 billion masks, 340 million protective suits, 115 million goggles, 96,700 ventilators, 225 million testing kits, and 40.29 million infrared thermometers to 200 countries and regions. According to data released by the General Administration of Customs, from March to the end of December in 2020, China's customs inspected and exported major epidemic prevention and control materials worth 438.5 billion yuan. During the epidemic, China was the first country to fully resume work by actively exporting medical supplies and exploited its advantages as the largest supplier of medical supplies.

At the same time, the encouraging development of the e-commerce economy does not limit the market to the domestic market. On June 8, the Canton Fair, originally scheduled to be held in Guangzhou, attempted to be held online for the first time. The strongest cross-border ecommerce platform and the all-time exclusive live broadcast room provide the technical basis for this online transaction. The Canton Fair held online is not only to open up China's market and increase trade surplus, but more importantly, it provides new possibilities for the globalization of trade with the help of the development of the e-commerce economy. The scale of domestic retail sales is 30 trillion yuan in China and the digital rate has exceeded $30 \%$. While China's foreign trade volume is 31 trillion yuan, digital is less than $10 \%$. The process of globalization and anti-globalization is going on simultaneously. China hopes to extend the life of globalization by exploring a new economic structure.
For China, attaching importance to the development of the domestic market does not mean giving up the international market. The economic development strategy of "Domestic-international Dual Circulation" also emphasizes the role of international circulation in promoting domestic circulation. The COVID-19 crisis has not only made China aware of destabilizing factors in the international community. International assistance and the integrated development of the world economy continue to testify to the importance of globalization for all countries of the world. While $\mathrm{Wu}$ Xiaoqiu acknowledged the importance of boosting domestic demand for China's economic growth, he also disagreed with the idea of closing China's supplies and demands. The closed economic model is difficult to balance, so China must continue to open up to the outside world to achieve real economic growth. In Zhong's research, he believes that if we still take the first globalization generally accepted by the academic community as the benchmark for comparison, it is easy to find that globalization continues to develop even under the impact of COVID-19, but with a contraction in speed and scope. A new adjustment in a dynamic mechanism is also needed. Therefore, China's "Domestic-international Dual Circulation" economic development model in response to the global economic recession caused by COVID-19 is not a manifestation of abandoning globalization or international cooperation, but an adjustment of economic policies in response to the new international situation [10].

\section{CONCLUSION}

As a crisis that has had a huge impact on the whole world, the coronavirus has caused a rapid recession of the world economy. Faced with a rapid economic downturn in a short period of time, the Chinese government chose to encourage the development of the e-commerce industry to revitalize the domestic market. Through this outbreak, China is also aware of the instability of the international market and the negative impact of globalization on countries around the world. In the 14th Five-year Plan, the Chinese government put forward the construction of a "Dual Circulation", especially emphasizing the strengthening of the leading role of the domestic market, to achieve the mutual promotion of the domestic market and the international market. This policy does not mean that China has made an antiglobalization decision. On the contrary, while exposing the fragility of globalization, the COVID-19 pandemic has also reminded countries of the importance of international cooperation. In response to the everchanging international situation, China has chosen to implement a "Dual Circulation" to explore new forms of international cooperation and revitalize economic globalization. 


\section{REFERENCES}

[1] "Real-time big data reporting on the epidemic." Last modified October 28, 2021. https://voice.baidu.com/act/newpneumonia/newpne umonia/?from=osari_aladin_banner\#tab4.

[2] Gopinath, Gita. "The Great Lockdown: Worst Economic Downturn Since the Great Depression." IMFBlog. Accessed April 14, 2020. https://blogs.imf.org/2020/04/14/the-greatlockdown-worst-economic-downturn-since-thegreat-depression/.

[3] "How does Alibaba thrive in SARS?" Accessed February $1, \quad 2020$. https://zhuanlan.zhihu.com/p/104562178.

[4] "China's economic countermeasures under the three crises: review and observation of 2003, 2008 and 2020." Accessed March 3, 2020.

[5] "China encourages the development of live broadcasting e-commerce industry. Many places have issued online marketing policies, and platforms such as Tiktok have been supported." Accessed September 3, 2020. http://zhengce.chinabaogao.com/it/2020/093513H2 2020.htm.

[6] Cyberspace Administration of China. "In the first quarter, the national e-commerce development momentum is rapid, the number of rural ecommerce exceeded 13 million.” Accessed May 04, 2020 .

[7] Anbound Group "The Fourteenth Five-Year Plan and Dual Circulation.” Accessed September 11, 2020.

[8] Zhao, Chen. "COVID-19 and European Integration." International Political Studies, no. 3, 2020.

[9] International Crisis Group. "COVID-19 and Conflict: Seven Trends to Watch.” International Crisis Group, 2020. http://www.jstor.org/stable/resrep31545.

[10] Zhong, Tengfei. "Slowbalization: COVID-19 Pandemic and China's External Economic Environment." Teaching and Research, no. 10, 2020: 69-80. 